\begin{tabular}{|c|c|c|c|c|c|c|}
\hline \multirow{4}{*}{ Impact Factor: } & ISRA (India) & $=3.117$ & SIS (USA) & $=0.912$ & ICV (Poland) & $=6.630$ \\
\hline & ISI (Dubai, UAE & $=0.829$ & РИНЦ (Russia) & $=0.156$ & PIF (India) & $=1.940$ \\
\hline & GIF (Australia) & $=0.564$ & ESJI (KZ) & $=8.716$ & IBI (India) & $=4.260$ \\
\hline & JIF & $=1.500$ & SJIF (Morocco) & $=5.667$ & OAJI (USA) & $=0.350$ \\
\hline
\end{tabular}

\section{SOI: 1.1/TAS DOI: 10.15863/TAS International Scientific Journal Theoretical \& Applied Science}

p-ISSN: 2308-4944 (print) e-ISSN: 2409-0085 (online)

Year: 2019 Issue: 05 Volume: 73

Published: $10.05 .2019 \quad \underline{\text { http://T-Science.org }}$
QR - Issue

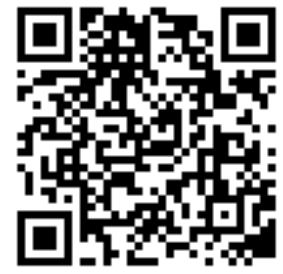

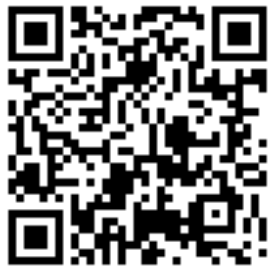

S.B. Muranov

teacher of the Chair of Fine Arts and Engineering

Graphics at SamSU

\title{
SOME ISSUES OF PREPARING FUTURE TEACHERS OF FINE ARTS AND APPLIED ARTS FOR INNOVATIVE ACTIVITY
} \begin{abstract}
requirements and their background in pedagogical activity. educational, requirements, preparation.

Language: English

\section{Introduction}

The radical changes that have taken place in Uzbekistan and the entire world community have a direct impact on the full-fledged human resource development process in the continuing education system. Future experts, including future teachers of descriptive and applied arts, will be able to grow in the process of change and take part in the implementation of such reforms.

Changes in national and international levels in the Republic of Uzbekistan over last years, such as renewal of cooperation agreements with countries that are closely associated with the whole of the country, and the inclusion of diversified investment in many sectors as a result of these agreements, take into account the foreign capabilities of future staff in future professional activities, or directly to foreign students in bachelors, masters and doctoral students abroad preparation of institutions, many of the leading higher educational institutions of foreign countries to open branches in the country, (such as Westminster, Singapore, Turin, Lomonosov Moscow State University, Mendeleev and Plekhanov Universities, etc.) and the development of inter-agency development in the system of cadres training.
\end{abstract}

Abstract: This article deals with some aspects of professional and pedagogical preparation of future bachelors and masters, students in higher education institutions. The example of teachers of applied arts is the appearance of educational, scientific, research, methodological, organizational-methodological, spiritual-enlightenment

Key words: experts, teacher-pedagogues, teachers of descriptive and applied arts, vocational, pedagogical, activity, baccalaureate, magistracy, educational, scientific-methodological, scientific-research, spiritual-

Citation: Muranov, S. B. (2019). Some issues of preparing future teachers of fine arts and applied arts for innovative activity. ISJ Theoretical \& Applied Science, 05 (73), 30-33.

Soi: http://s-o-i.org/1.1/TAS-05-73-7 Doi: crossef https://dx.doi.org/10.15863/TAS.2019.05.73.7

\section{Materials and Methods}

The fact that many branches of higher education institutions throughout the country have opened in the provinces are the clear example of such positive changes. The implementation of reforms in the fields of industry and art, culture, education, engineering and construction in the people and agriculture needs the professionalism of the staff prepared in such new conditions in different conditions.

It is important to pay attention to the future aspects of the training of future teachers in the up-todate professional training. This is stated in the Resolution of the President of the Republic of Uzbekistan Sh.M.Mirziyoev PR-2909 "On Measures for the Further Development of Higher Education System" approved by the President of the Republic of Uzbekistan on April 20, 2017, as "... improving the moral and spiritual content of higher education deeply enthusiastic young people to the ideas of independence and the spirit of loyalty to the national traditions of humanism, to carry out wide-ranging, educative and upbringing work to strengthen their immunobiological and critical thinking in their ideas and ideologies "(1.p.3).

Thus, this quotation suggests that future specialists have to develop a wider range of educational activities in higher education institutions.

However, some professors and teachers working at universities consider that, "It is not absolutely necessary for the students to rear up and upbring the students because they are already formed persons. They have their passports of citizenship. Family and 


\begin{tabular}{|c|c|c|c|c|c|c|}
\hline \multirow{4}{*}{ Impact Factor: } & ISRA (India) & $=3.117$ & SIS (USA) & $=0.912$ & ICV (Poland) & $=6.630$ \\
\hline & ISI (Dubai, UAI & $=0.829$ & РИНЦ (Russia & $=0.156$ & PIF (India) & $=1.940$ \\
\hline & GIF (Australia) & $=0.564$ & ESJI (KZ) & $=8.716$ & IBI (India) & $=4.260$ \\
\hline & JIF & $=1.500$ & SJIF (Morocco & $=5.667$ & OAJI (USA) & $=0.350$ \\
\hline
\end{tabular}

neighborhoods are responsible for their upbringing, and higher education institutions do not have to spend time preparing for it. There is a need for more training in their field of expertise. "

For example, it is known that the purpose of the 'Objectives triangle' is to analyze the 4-year bachelor's curriculum for the direction of education, 5110800 -fine arts and engineering graphics, issued in 2012 for students $4^{\text {th }}$ course years in 2018-2019 academic year. Total hours are 9288 hours, including "Humanities and Socio-Economic Sciences" in the 1st Block of the University for general educational purposes, consist of 12-15 titles and 1,584 hours.

In this regard, it is intended to form and develop the knowledge, skills, and intellectual abilities of the future specialist in the historical, legal, philosophical, spiritual, cultural, political, aesthetic and ethic concepts. Because of the artistic and engineering graphics included in the profession of teaching profession, it is important to form the quality of the above-mentioned knowledge and skills of the abovementioned cadres for 5110800 educational direction. In addition, professionals are also involved in the perfection of the mind and spiritual world of future students. Therefore, first of all, such consciousness and outlook should be fully formed.

Subjects like 'General and Occupational syllabus' in 3 and 4 blocks, were allocated 660 hours at 3732 hours correspondingly. In the first block, 1316 subjects were assigned and 6-7 units were given to the next block. Also, additional subjects are 450 hours (5 blocks) and 756 hours of undergraduate study in 270 hours (these hours are organized by the Ministry of Higher and Secondary Special Education and the rectors of higher educational establishments, starting from the 2018 academic year, and others were added to the block), attestation was 918 hours.

Some subjects in these blocks, such as "plastics anatomy" in Block 2, 136 hours, age physiology and hygiene (68 hours), "general psychology" in block 3300 hours, "general pedagogy" - 336 hours. Such disciplines as "computer graphics" 140 hours, and "Fundamentals of medical science" (260 hours) in 5th block, are devoted to the purposes of the department and are planned to be delegated to the departments organized by faculties and higher education institutions and organized by other specialized faculties.

The techniques and skills of 'teaching descriptive arts and engineering graphics' (276 hours) and 'drawing' (386 hours), 'drawing geometry '(252 hours), 'Technologies and projecting teaching art and engineering graphics' (158 hours), ' architecture and building' (190 hours) are aimed at improving the methods, methods and techniques of teaching and teaching these subjects directly.

Of course, in most cases, the graduates of higher education institutions, engineers, agronomists, builders, artisans (pictorial, applied art, musical art, sculptors, etc.) work continuously in educational institutions, that is, pedagogical and educational activities, they need knowledge, skills, skills acquired from the study of psychological, methodological subjects.

However, in today's conditions, highly skilled and knowledgeable cadres who have pedagogical, educational and enlightenment activities in arts and crafts, descriptive and applied arts, graphic arts, even academic, state awards and prizes, don't continue to focus on these aspects of the problem.

Therefore, if these cadres which haven't suitable professional knowledge, skills, and mastery, do not comply with pedagogical competences, they often lead to corruption, that is, they do not always have a clear idea of the level of knowledge, skills of their students, graduates, they do not have a clear design of the process. That is why every specialist involved in pedagogical activities must have to achieve methodological, psychological, pedagogical, innovative knowledge, skills, and mastery.

That is, if they are non-pedagogues, they have pedagogical, psychological or retraining or if they have pedagogical knowledge, every 3-5 years of innovative vocational and pedagogical professional development courses.

In order to fulfill the goals and objectives of faculties and higher education institutions, many educational, spiritual, cultural, political, ideological, theoretical, methodological, organizational, administrative, massive, educational activities which are given and aren't given in these curricula.

Such educational and training events include the following:

1) Practice (planner, pedagogical museum, field production and diploma defense, etc.), spiritual hours and days, group meetings, clubs (specialization, discipline, masterful hands, modeling, product development, applied, fine arts and folk music) craftsmanship, degraded, theatrical, ecological, economic and other types of activities (veterans and war veterans, advanced state, sport, academic degrees, prize winners, etc.) nights, the organization of dedicated festivals, participation in various experiments and sessions, carrying out independent test works (practical, creative, written, verbal, targeted, scientific etc.), participation in creative associations of students, science Olympiads, competitions, museums, historical monuments, places of worship, sacred places, construction, nature, mountains, gardens, crops, fields and other scientific and artistic centers, indices (persons with disabilities, and other special education institutions, patients, orphanages, nurseries, general and secondary specialized vocational education institutions, art schools and colleges, etc.), in hashar (participation in charitable donations, participation on contractual 


\begin{tabular}{|c|c|c|c|c|c|c|}
\hline \multirow{4}{*}{ Impact Factor: } & ISRA (India) & $=3.117$ & SIS (USA) & $=0.912$ & ICV (Poland) & $=6.630$ \\
\hline & ISI (Dubai, UAI & $=0.829$ & РИНЦ (Russia & $=0.156$ & PIF (India) & $=1.940$ \\
\hline & GIF (Australia) & $=0.564$ & ESJI (KZ) & $=8.716$ & IBI (India) & $=4.260$ \\
\hline & JIF & $=1.500$ & SJIF (Morocco & $=5.667$ & OAJI (USA) & $=0.350$ \\
\hline
\end{tabular}

basis), participation in special purpose trips, conferences and seminars participation and so on.

As can be seen from the foregoing, these activities are very diverse and various. Their locations and goals, tasks, times, sizes and types are lots. In some cases, they are so prematurely unstable that they may have a negative effect on the learning process. Thus, the main objectives of theoretical, methodological, organizational and practical training of theoretical and practical practitioners are to define which, when, where, to what extent, what is the purpose and the target of these activities, the strict day-to-day, hourly regulation, goals and objectives, and place must be determined before the location.

Only then these events will serve the "triangle of goals" and won't interfere with the current process.

For this purpose, it is necessary to address the modern purpose of preparing future teachers of descriptive and applied arts. Academician V.P.Bespalko describes the goals and objectives of preparing future specialists, which is the "social order at the top of the Triangle of Objectives". At the other side of the "Triangle of Objectives", the Didactic scientist points out that the widest readiness of the location of faculties and departments is to combine the social order with the "International Standard Level" (2.15).

Indeed, large-scale multidimensional work in the process of professional training of future staffs has resulted in their faster adaptation to complex multisectoral professional and pedagogical activities. Acting as an Acting Actor, he is a reliable and active member of the educational process. Because, young specialists who graduate from higher educational institutions just do not have the opportunity to teach independently when they go to professional pedagogical activities and education.

The most important thing is to do the academic hours of the teacher. To do so, they will undergo a 9,288-hour bachelor's degree study and a 4560-hour (2420 academic hours) of master's curriculum. This is understandable, but where do these teachers get prepared for the training, methodic, organizationalmethodological, scientific-research, and spiritualenlightened hours that are mentioned in the above "Time standards" that are almost equally educational hours?

Especially in the recent years, the university has been assigned as a "Mandatory Requirements" by the management of the teaching staff to engage in scientific research and methodology. Certainly, these requirements must be met so that they can have academic degrees and academic titles in the "image" of the teacher of the university.

But the second aspect of the main issue is that all professors and teachers are capable of carrying out research and methodological work? or how did they prepare for this work, from the "supporter"? That is, how well do they know the technology of doing these tasks? Or are the fees and criteria defined for the many spiritual and moral work done by the young coaching teacher in directing students' academic groups? Have these criteria been put to good use as a result of sociological, economic research?

\section{Conclusion}

Thus, the future artistic and applied arts teachers are being updated in the future for their professional career, there are some conclusions, suggestions, and comments for the above factors to be considered and the process itself is considered to belong to a particular research. The further improvement of this process can be summarized as the following suggestions and recommendations.

1. Improving the technology of preparing future personnel for professional activity should consider the peculiarity of the economy in each branch and the role of the department, faculty of the higher educational institution in the social order.

2. It is necessary to pay attention to the pedagogical and methodical aspects of the preparation of future teachers of fine and applied arts for professional activity. Because many aspects of pedagogical activity are manifested in the methodological (methodic) educational and organizational aspects.

3. The future teacher will have to participate in carrying out of their research in preparation of specialists for professional pedagogical activity. Because the pedagogical process is composed of many unusual situations. Teachers, in most cases, have to anticipate, observe, summarize, and prepare them.

4. It is necessary to carry out many formal and informal methodological standard educational documents in the pedagogical activity. It is therefore desirable for future teachers to prepare, edit, and correct various documents from the initial stages.

\section{References:}

1. Mirziyoev, S. M. (2017). The Decree of the President of the Republic of Uzbekistan "On measures for further development of the higher education system" of the President of the Republic of Uzbekistan, April 20, 2017, PQ 2909. 


\begin{tabular}{|c|c|c|c|c|c|c|}
\hline \multirow{4}{*}{ Impact Factor: } & ISRA (India) & $=3.117$ & SIS (USA) & $=0.912$ & ICV (Poland) & $=6.630$ \\
\hline & ISI (Dubai, UAE & $=0.829$ & РИНЦ (Russia & $=0.156$ & PIF (India) & $=1.940$ \\
\hline & GIF (Australia) & $=0.564$ & ESJI (KZ) & $=8.716$ & IBI (India) & $=4.260$ \\
\hline & JIF & $=1.500$ & SJIF (Morocce & $=5.667$ & OAJI (USA) & $=0.350$ \\
\hline
\end{tabular}

2. Mirziyoev, S. M. (2016). Speech on the united meeting of Oliy Majlis Houses devoted to the ceremony of the President of the Republic of Uzbekistan on the theme "we shall build free and flourishing, democratic Uzbekistan with our generous people”. (p.28). Tashkent: Uzbekistan.

3. Karimov, I. A. (2008). Higher spiritualuty invincible power. (p.176). Tashkent: Manaviyat.

4. Abdirasilov, S. F., \& Nurtoev, U. N. (2015). Technology of teaching the subhect of art in general educational schools. (p.11). Tashkent: TSPU.

5. Azizkhodhaeva, N. N. (2003). Pedagogical technologies and pedagogical mastery. Tashkent: Moliya.

6. Ananev, B. G. (2001). about problrms of modern humanity. (p.272). P.: Piter.

7. Boymetov, B. (1997). Painting. Manual for pedagogical institutes and universities. (pp.5556). Tashkent: ТДПУ.

8. Rahmonov, I. (1992). Didactic games in drawing. Tashkent: Ukituvchi.

9. Ruziev, E. I., \& Ashirboev, A. O. (2010). Methodics of teaching engineering graphics. Tashkent., Publishing „Fan va texnologiya“.

10. Slactenin, A. A. (2004). Professionality of the teacher as pedagogical culture. Pedagogical education and science, № 5 .
11. Slactenin, V. A., Isaev, I. F., Mishenko, A. I., \& Shiyaniv, E. N. (1997). Pedagogics. / Manual for students of pedagogical educational institutions. (pp.298-301). Moscow: Shkola-Press.

12. Bespalko, B. I., \& Tatur, V. P. (1989). Systematic-methodic providing of educationalupbringing training process of specialists. (p.142). Moscow: Higher school.

13. (2015). Order №42 (698) of Rules of determination of the educational, scientificallymethodical, research, organizational, methodological, moral and educational work of the teaching staff of the higher educational institutions of the Ministry of Higher and Secondary Special Education of the Republic of Uzbekistan from October 26/ was approved as the order of the Minister of Justice of the Republic of Uzbekistan from October 19, 2015. Registration No. 2720.

14. (2018). The educational curriculum of the Ministry of Higher and Secondary Special Education of the Republic of Uzbekistan on specialty 5110800- fine arts and engineering graphics for 2018 academic year. 